\title{
Sociedade da aprendizagem, Instituto Nacional de Cinema Educativo (INCE) e TV Escola: governamento dos sujeitos via curtas-metragens de animação ${ }^{1}$
}

\author{
Bruno da Mata Farias' (D) \\ Valéria Cazettal (1)
}

\section{RESUMO}

Abordaremos, neste texto, o limiar das políticas públicas audiovisuais brasileiras com finalidades educativas e escolares. Foram selecionadas duas animações: " $\mathrm{H}_{2} \mathrm{O}$ ", lançada em 1962 e produzida para o Instituto Nacional de Cinema Educativo (INCE); e "De Onde Vem?", realizada em 2002 pelos canais de televisão TV Escola e TV PinGuim. Com um intervalo de quarenta e dois anos entre uma e outra, as animações foram analisadas desde suas enunciações verbais e imagéticas com o propósito de evidenciar deslocamentos e rupturas discursivas concernentes à sociedade da aprendizagem. Para tanto, buscamos conectar dois ferramentais teórico-metodológicos, quais sejam, a desmontagem didihubermaniana com a análise discursiva de inspiração foucaultiana.

PALAVRAS-CHAVE

Instituto Nacional de Cinema Educativo; TV Escola; audiovisual e políticas públicas; desmontagem didihubermaniana; análise do discurso foucaultiana.

1 Artigo oriundo da dissertação de mestrado de Bruno da Mata Farias (2020), realizada junto ao Programa de Pós- Graduação em Estudos Culturais da Escola de Artes, Ciências e Humanidade, da Universidade de São Paulo (EACH/USP), intitulada Sociedade da Aprendizagem: uma experiência visual, divertida e fabulada, sob orientação da profa. Valéria Cazetta.

'Universidade de São Paulo, São Paulo, SP, Brasil. 


\section{LEARNING SOCIETY, INSTITUTO NACIONAL DE CINEMA EDUCATIVO (INCE) AND TV ESCOLA: GOVERNMENT OF SUBJECTS BY ANIMATION SHORT FILMS}

\section{ABSTRACT}

In this article we approach the threshold of Brazilian audiovisual public policies for educational and school purposes. Two animations were selected: " $\mathrm{H}_{2} \mathrm{O}$ ", released in 1962, was produced for the National Institute of Educational Film (INCE); and "Where Do You Come From?", produced in 2002 by TV Escola and TV PinGuim. With a hiatus of forty-two years between them, the animations were analyzed their verbal and visual statements with the purpose of highlighting discursive displacements and disruptions related to the learning society. To do so, we assemble two theoretical and methodological procedures, namely, the Didihubermanian disassembly procedure and a Foucauldian inspired discursive analysis.

\section{KEYWORDS}

Instituto Nacional de Cinema Educativo; TV Escola; audiovisual and public policies; didihubermanian disassembly; foucauldian discursive analysis.

\section{SOCIEDAD DE APRENDIZAJE, INSTITUTO NACIONAL DE CINEMA EDUCATIVO (INCE) Y TV ESCOLA: GOBIERNO DE SUJETOS POR CORTOMETRAJES DE ANIMACIÓN}

\section{RESUMEN}

Abordaremos en este texto, el umbral de las políticas públicas audiovisuales brasileras con finalidades educativas y escolares. Se seleccionaron dos animaciones: " $\mathrm{H}_{2} \mathrm{O}$ ", estrenada en 1962 y producida para el Instituto Nacional de Cinema Educativo (INCE); “ "De donde viene", realizada en 2002 por el canal de televisión TV Escola y por el estúdio de animación TV PinGuim. Con un intervalo de cuarenta y dos años entre ellas, las animaciones fueron analizadas desde sus expresiones verbales y imagéticos con el propósito de evidenciar dislocaciones y rupturas discursivas concernientes a la sociedad del aprendizaje. Por lo tanto, buscamos conectar dos herramientas teórico-metodológicas, como el desmontaje didihubermaniana con el análisis de discurso de inspiración foucaultiana.

\section{PALABRAS CLAVE}

Instituto Nacional de Cinema Educativo; TV Escola; audiovisual e políticas públicas; desmontage didihubermaniana; análisis de discurso foucaultiano. 


\section{INTRODUÇÃO}

Há cerca de oitenta anos o Estado brasileiro, via Ministério da Educação (MEC), tem operacionalizado políticas públicas audiovisuais educativas perpassando o cinema, a televisão e, atualmente, os streamings ${ }^{2}$. Tais políticas podem ser sistematizadas, grosso modo, em torno de três grandes projetos, quais sejam, Instituto Nacional de Cinema Educativo (INCE), TV Educativa e TV Escola, que consistem em ações governamentais que contribuem para caracterizar, por intermédio de dispositivos audiovisuais, a sociedade educativa ou cidade educativa (Noguera-Ramírez, 2011), também chamada de sociedade da aprendizagem, sociedade do conhecimento ou, ainda, sociedade da informação. Essas caracterizações são tributárias da compreensão discursiva de que as Tecnologias da Informação e Comunicação (TIC) modificaram o modo de acessar as informações e, por conseguinte, o conhecimento e as ambiências voltadas para os processos de ensino e aprendizagem; ambiências estas que não mais seriam monopólio institucional e espacial das escolas ou dos espaços formais de educação.

Para autores e autoras ancorados/as na sociedade da aprendizagem (Gadotti, 2000; Takahashi, 2000; Duarte, 2001; Gasque e Tescarolo, 2004; Burch, 2005; Castells, 2006; Fabela, 2005; Freire, 2007), as TIC forjaram um novo paradigma educacional por meio do qual as informações estariam à disposição dos sujeitos, que seriam responsáveis por suas aprendizagens e por desenvolver habilidades, competências e atitudes para aprenderem sozinhos a acessar informações variadas, transformando-as em conhecimento.

No livro Pedagogia e governamentalidade ou da modernidade como uma sociedade educativa, Carlos Ernesto Noguera-Ramírez apresenta a arqueogenealogia do que ele chama de "sociedade educativa", oriunda da sociedade pós-capitalista, cuja ênfase no conhecimento implicou "uma transformação na forma de pensar a educação: esta não pode mais ser um monopólio das escolas" (Noguera-Ramírez, 2011,p. 14).Em sua esteira, podemos afirmar que vivemos em sociedades nas quais todas as ambiências e espaços são passíveis de educar, de modo que o adjetivo educativo, tido como atributo central do presente, está ancorado na emergência, ainda na Modernidade, de uma "sociedade educativa". Isso não significa dizer que a Modernidade "tenha tido uma causa educativa ou que a educação tenha sido sua causa" (Noguera-Ramírez, 2011, p. 21), mas que as problemáticas com as quais homens e mulheres dos séculos XVII ao XX tiveram que lidar foram problemáticas pedagógicas e educacionais, no sentido de suas implicações serem políticas, econômicas e culturais.

Em termos foucaultianos, à exigência de o sujeito educar a si mesmo permanentemente podemos chamar de governamentalidade do aprendizado. Ler a modernidade, perspectivada desde a governamentalidade, implica distinguir três discursos que, por sua vez, estão agenciados a três tipos de práticas pedagógicas. Recuperemos, na íntegra, a síntese feita por Noguera-Ramírez (2011, p. 21):

2 Noção que diz respeito à "transmissão instantânea de dados multimídia (como vídeo, áudio e jogos), que dispensa download” (Folha de S.Paulo, 2018, p. 363). 
O primeiro, localizado entre os séculos XVII e XVIII, poderia ser denominado "o momento da instrução" ou "momento do ensino", generalizado pela estrita relação estabelecida entre práticas de ensino, práticas de "polícia" e processo de constituição da "razão do Estado" [...]; o segundo momento, iniciado no fim do século XVIII, seria denominado de o momento da "educação liberal", devido ao aparecimento do novo conceito de educação e sua estreita ligação com a problemática da liberdade e da natureza humana, tal como foi formulada nos discursos do Iluminismo. Por último, desde o fim do século XIX, a emergência do conceito de "aprendizagem" marcaria a passagem da educação liberal para aquilo que se chamaria posteriormente a "sociedade da aprendizagem", "sociedade aprendente" ou "cidade educativa", graças, de uma parte, à extensão da função educativa além da escola e, de outra, à consequente exigência, para o indivíduo habitante desse novo espaço social, de um aprendizado constante e ao longo da vida, exigência que leva a sua consideração como aprendiz permanente, vitalício.

Esse modelo de sociedade da aprendizagem tem se consolidado, ao menos no Ocidente, em decorrência dos avanços do neoliberalismo a partir do aprofundamento das reformas dos Estados-nação, que consistem na diminuição da oferta de serviços públicos à população, resultando no aumento e na intensificação da autorregulação dos sujeitos. Se na emergência da modernidade liberal a função do Estado era a instrução, na contemporaneidade essa função foi deslocada para os sujeitos, que se responsabilizaram por sua própria aprendizagem. Essa nova condição ou modo de educação evidencia-se por meio dos diversos dispositivos tecnológicos de educação a distância, de tutoriais e de outros tipos de plataformas.

Assim, se os conceitos de doctrina e disciplina governaram as reflexões pedagógicas durante a Idade Média; se institutio e eruditio dominaram o pensamento pedagógico dao séculos XVI e XVII; se educação, instrução e Bildung prevaleceram entre o fim do século XVIII e o fim do século XIX, o conceito de aprendizagem (learning) será o conceito pedagógico preponderante do século XX e, segundo parece, dos primórdios do século XXI. (Noguera-Ramírez, 2011, p. 230)

$\mathrm{O}$ autor assevera, contudo, que a sociedade da informação/sociedade do conhecimento desenvolveu tendências pedagógicas nos seguintes termos: aprendizagem ao longo da vida, aprendiz permanente, abordagem por competências e educação por competências. Essas tendências, chamadas de pedagogias contemporâneas, seriam o aprimoramento de uma nova governamentalidade, circunscrita em torno dos indivíduos entre si e não mais entre a razão do Estado para com os indivíduos. O processo contínuo de aprimoramento dispensa o papel do Estado como instituição central na organização, regulação e oferecimento do conhecimento, centralizando no próprio sujeito a competência para aprender.

Dessa forma, a intervenção do Estado será sobre os interesses particulares e coletivos dos indivíduos, afinal, "já não se precisa agir diretamente sobre o indivíduo, o alvo não é tanto o corpo do indivíduo, como era o caso da disciplina, 
mas o interesse do sujeito, isto é, aquilo que o movimenta, aquilo que é a condição para sua ação, digamos assim, sua 'motivação"' (Noguera-Ramírez, 2011, p. 233). Nessa perspectiva, o investimento da máquina pública será sobre os interesses dos indivíduos e aquilo que os motiva a aprender, estimulando o desejo pelo aprender a aprender de modo vitalício. Por um lado, somente a partir desse investimento foi possível para o sujeito vislumbrar quais as vantagens da aprendizagem contínua para si. Por outro, há um apelo constante, observado nas publicidades das instituições de ensino superior e técnico, acerca dos benefícios para o aprimoramento contínuo, tais como melhores empregos e salários, experiências internacionais e incentivos para estudantes que não possuem habilidades e competências para aprenderem sozinhos.

Em vista disso, objetivamos explorar como se deu o espraiamento de dois acontecimentos discursivos da sociedade da aprendizagem: os curtas-metragens de animação $\mathrm{H}_{2} \mathrm{O}^{3}$ e De Onde Vem o Fósforo? , produzidos nos anos de 1962 e de 2002, respectivamente. Resultado de duas políticas públicas brasileiras sobre o audiovisual educativo, o primeiro foi produzido pelo INCE, instituição criada em 1936; e o segundo trata-se de uma produção do canal de televisão TV Escola, fundado em 1996. A despeito de um giro de 42 anos separar o primeiro do segundo curta de animação, ambos são endereçados para o ensino de ciências. Nesse sentido, realizamos uma digressão até a primeira metade do século $\mathrm{XX}$, objetivando circunscrever, ainda que laconicamente, a emergência do INCE, e os contextos de criação das emissoras de televisão TV Educativa do Rio de Janeiro, também conhecida como TVE Brasil ou TVE RJ, e da TV Escola ${ }^{5}$. O referido arco temporal compreende quase um século entre a criação e a implementação dessas três políticas públicas direcionadas ao audiovisual e sua distribuição na rede escolar brasileira.

O segundo objetivo delineado é mais específico: analisar as enunciações verbais e imagéticas dos dois curtas-metragens de animação supracitados. Para tanto, empregamos dois ferramentais metodológicos: o primeiro, vinculado ao procedimento da desmontagem didihubermaniana (Didi-Huberman, 2017), com a finalidade de analisar as enunciações imagéticas; e, o segundo, de inspiração foucaultiana (Foucault, 2013a), com o intuito de analisar as enunciações textuais. Compreendemos como desmontagem o tratamento dado por nós às duas animações selecionadas, com o propósito de retirar as imagens do lugar comum/familiar/ acostumado que ocupam na educação visual contemporânea. Para proceder dessa

3 Disponível em: http://www.bcc.org.br/filmes/443429. Acesso em: 25 maio 2019

4 Disponível em: https://tvescola.org.br/videos/de-onde-vem-de-onde-vem-o-fosforo/\#mais-informacoes. Acesso em: 25 maio 2019.

5 A contar do mês de dezembro de 2019, o contrato com a organização responsável por gerir a TV, desde sua fundação, a Associação de Comunicação Educativa Roquette Pinto (ACERP) (http://roquettepinto.org.br/), ainda não havia sido renovado, ocasionando a interrupção da veiculação do programa pelo MEC. Até o presente momento a plataforma da TV continua online e seus conteúdos ainda estão disponíveis para acesso em seu website. $\mathrm{E}$ a transmissão continua sendo realizada tanto por sinal digital, quanto analógico, porém não sabemos especificar se o governo federal, via Ministério da Educação, continuará operando tais transmissões. 
maneira, paralisamos o movimento de animação dos referidos curtas-metragens para desmontá-los em fotogramas e remontá-los em uma outra série. Concernente à análise textual empregada, nos interessou destacar os sujeitos das animações, particularmente os lugares sociais assumidos por eles ao falarem; o quê e para quem enunciam; e, por último, como se apresentam ao mundo. A partir das duas abordagens, problematizamos o conjunto das enunciações que formam uma teia discursiva articulada às imagens em movimento ${ }^{6}$ ou, melhor dizendo, aos audiovisuais ou curtas-metragens de animação educativos no contexto da sociedade da aprendizagem.

Concernentes às políticas públicas audiovisuais, podemos afirmar que a finalidade do INCE foi produzir conteúdos que seriam reproduzidos tanto nas salas de aula das instituições escolares quanto em ambientes de educação não formal como museus, feiras de ciências e exposições científicas (Catelli, 2007). De modo similar, é o que tem ocorrido com as emissoras de televisão como a TV Educativa (TV Brasil) e a TV Escola, esta última transformada em streaming, que, ao alterar a noção de ambiência, tem desterritorializado os espaços de ensino e aprendizagem, tornando-os, no limite, moventes. Ou seja, com o alcance capilarizado dessas ambiências desterritorializadas e desescolarizadas, ampliaram-se as possibilidades de acesso aos conteúdos dessas programações em qualquer ambiência. Atualmente, via streaming, essas programações podem ser vistas em casa ou em contextos como metrôs, trens, ônibus, entre outros lugares de passagem. Por isso, a noção de deslocamento da espacialidade constitui nossa primeira análise acerca das duas animações. Desde o INCE até o TV Escola, houve investimentos para diversificar as possibilidades de ensino e aprendizagem para fora da ambiência escolar. Antes de mais nada vale ressaltar que, nesse estudo, não advogaremos em prol da escolarização versus desescolarização, mas apresentaremos tão somente as linhas de forças de ambas.

\section{POLÍTICAS PÚBLICAS AUDIOVISUAIS EDUCATIVAS NO BRASIL}

\section{INSTITUTO NACIONAL DO CINEMA EDUCATIVO}

A ideia de empregar o cinema nas ambiências escolares não é uma temática do contemporâneo. Vale lembrar o impacto de duas publicações que acabaram por delinear, para todo o território nacional, um projeto de educação articulado em torno da linguagem audiovisual voltada para uma produção cinematográfica específica: o cinema com fins educacionais. Uma delas trata-se do Decreto no 2.940, publicado em 22 de novembro de 1928 por Fernando Azevedo, diretor de Instrução

6 "As condições determinantes do cinema são as seguintes: não apenas a foto, mas a foto instantânea (a fotografia pousada pertence a uma outra linhagem); a equidistância dos instantâneos; a transferência dessa equidistância para um suporte que constitui um 'filme' [...]. E nesse sentido que o cinema é o sistema que reproduz o movimento em função do instante qualquer, isto é, em função de momentos equidistantes, escolhidos de modo a dar a impressão de continuidade" (Deleuze, 2018, p. 18). 
Pública do Distrito Federal no período de 1927 a 1930, já sob o primeiro governo do presidente Getúlio Vargas, de 1930 a 1945 (Bruzzo, 2004; Camara, 2011). A segunda publicação concerne ao Manifesto dos Pioneiros da Educação Nova, de 1932 (Azevedo et al., 1984).

Voltemos para o Decreto no 2.940. Ao estabelecer uma reforma no interior da escola, alterando desde sua organização aos métodos empregados, para assim renová-la, Fernando de Azevedo assegurou o papel do cinema nessa empreitada renovadora. No referido decreto lê-se:

As escolas de ensino primário, normal, doméstico e profissional, quando funcionarem em edifícios próprios, terão salas destinadas à instalação de aparelhos de projeção fixa e animada para fins meramente educativos.

O cinema será utilizado exclusivamente como instrumento de educação e como auxiliar do ensino que facilite a ação do mestre sem substituí-lo.

O cinema será utilizado sobretudo para ensino científico, geográfico, histórico e artístico.

A projeção animada será aproveitada como aparelho de vulgarização e demonstração de conhecimentos, nos cursos populares noturnos e nos cursos de conferências.

A Diretoria Geral de Instrução Pública orientará e procurará desenvolver por todas as formas, e mediante a ação direta dos inspetores escolares, o movimento em favor do cinema educativo. (Distrito Federal, 1928)

O Manifesto propõe, por sua vez, a utilização de todos os meios e recursos necessários para ensinar: "a escola deve utilizar, em seu proveito, com maior amplitude possível, todos os recursos formidáveis, como a imprensa, o disco, o cinema e o rádio" (Azevedo et al., 1984, p. 423). Inclusive uma parte do grupo de educadores signatária do Manifesto, incluindo Fernando Azevedo, era defensora do emprego do cinema na escola (Calabre, 2009).

Em decorrência de diversas pressões políticas, incluso as reivindicações de artistas e intelectuais que também haviam subscrito o Manifesto, Getúlio Vargas sancionou em abril de 1932, após a publicação do Manifesto, o Decreto no 21.240, no qual destacamos:

Considerando que o cinema, sobre ser um meio de diversão, de que o público já não prescinde, oferece largas possibilidades de atuação em beneficio da cultura popular, desde que convenientemente regulamentado;

Considerando que os favores fiscais solicitados pelos interessados na indústria e no comércio cinematográfico, uma vez concedidos mediante compensações de ordem educativa, virão incrementar, de fato, a feição cultural que o cinema deve ter, 
Considerando que a redução dos direitos de importação dos filmes impressos virá permitir a reabertura de grande número de casas de exibição, com o que lograrão trabalho numerosos desempregados;

Considerando, também, que a importação do flme virgem, negativo e positivo, deve ser facilitada, porque é matéria prima indispensável ao surto da indústria cinematográfica no país;

Considerando que o filme documentário, seja de caráter cientifico, histórico, artístico, literário e industrial, representa, na atualidade, um instrumento de inigualável vantagem, para a instrução do público e propaganda do país, dentro e fora das fronteiras;

Considerando que os filmes educativos são material de ensino, visto permitirem assistência cultural, cora vantagens especiais de atuação direta sobre as grandes massas populares e, mesmo, sobre analfabetos. (Brasil, 1932, grifos nossos)

De modo geral, nessas considerações normativas, Vargas asseverava que os filmes educativos eram materiais de ensino, permitindo a assistência cultural para a educação das massas. Além disso, de acordo com o Art. $15^{\circ}$ do mesmo decreto, seria encargo do governo federal, via Ministério da Educação e Saúde, efetuar convênios cinematográficos educativos junto às locadoras de filme, objetivando realizar cinejornais ${ }^{7}$; promover incentivos e facilidades às empresas nacionais produtoras de filmes; e, por fim, apoiar o cinema escolar.

Em 1936, quatro anos após a publicação do Manifesto e do decreto, o INCE foi regulamentado junto ao Ministério da Educação e Saúde. No cerimonial de lançamento das futuras instalações dessa instituição, o ministro da Educação e Saúde na época, Gustavo Capanema Filho, saudou dois personagens emblemáticos da empreitada do cinema educativo brasileiro: Álvaro de Osório de Almeida e Edgard Roquette-Pinto (1884-1954). O primeiro foi diretor honorário da Rádio Sociedade, formada por membros da Associação Brasileira de Ciências; o segundo ${ }^{8}$, além de

7 Diz respeito a "materiais fílmicos com larga circulação no país e de produção constante desde a segunda década do século XX até 1980, quando o gênero se esgotou” (Souza, 2003, p. 43). Esse tipo de produção cinematográfica brasileira foi "uma das formas de propaganda do regime ditatorial instituído em 1937. A sua produção foi feita, primeiro, pelo Departamento Nacional de Propaganda - DNP - e, depois, pelo Departamento de Imprensa e Propaganda - DIP" (Souza, 2003, p. 43).

8 Roquette-Pinto foi um médico legista, professor, escritor, eugenista, antropólogo, etnólogo e ensaísta brasileiro. Seu interesse pelo cinema é anterior à criação do INCE. "De fato, o emprego do cinema como auxiliar na pesquisa científica e no ensino encontra seus registros em 1910, quando foi iniciada, por Roquette, a filmoteca do $\mathrm{Mu}-$ seu Nacional, com o objetivo de fazer registros científicos e divulgação da ciência. Ela foi enriquecida mais tarde com os documentários produzidos pela Comissão Rondon. Durante os trabalhos da comissão, na região norte, foram registrados por sua equipe, em películas, aspectos diversos das explorações geográficas, botânicas, zoológicas e etnográficas" (Galvão, 2004, p. 31-32). 
seus méritos científicos e de sua contribuição na criação da Rádio Sociedade, foi considerado precursor da radiodifusão no Brasil e um dos principais responsáveis pela criação do INCE, idealizando inclusive o decreto 21.240 sancionado por Vargas. Ainda sobre Roquette-Pinto, Capanema Filho manifestou-se da seguinte maneira:

Brasileiro que, dando à sua vida um sentido de sabedoria e beleza, trouxe à educação brasileira dois poderosos e inéditos instrumentos, o rádio e o cinema [...]. O senhor Roquette-Pinto é um dos nossos mais puros patriotas. Um dos nossos maiores homens de cultura. Pode ser considerado, sob muitos aspectos, como um feiticeiro que pratica ante o auditório maravilhado, as artes que recolheu dos livros e da natureza. Apenas ele difere dos demais feiticeiros, quando ensina ao público a infinidade destas artes. (Brasil, 1936, transcrição nossa9 ${ }^{9}$ )

Tal "feitiçaria" seria atribuição de Roquette-Pinto ao manusear e operar diversos conteúdos relativos à ampla produção audiovisual educativa brasileira, marcando sua gestão no INCE. Dentre esses conteúdos estava a forja da identidade nacional e a divulgação científica. Inclusive, em 1938, foram listados, aproximadamente, 1.391 projetores nas escolas brasileiras (Schvarzman, 2000). Com a saída de Roquette-Pinto do INCE, em 1947, o repertório temático filmográfico contemplado pelo INCE passou "a girar mais em torno da educação rural, da musicalidade e da regionalidade do país" (Andrade, 2018, p. 85).

Assim, a trajetória do INCE pode ser dividida, grosso modo, em dois momentos. Um englobando os dez primeiros anos de sua criação, no qual foram produzidos filmes tanto de caráter documental sobre pesquisas científicas quanto de temáticas variadas acerca da ciência brasileira. O segundo momento refere-se ao período entre 1947, ano em que Roquette-Pinto aposenta-se, e 1966, momento no qual são encerradas as atividades do INCE. Nesse período de quase 20 anos, a produção fílmica do Instituto foi dirigida pelo cineasta Humberto Mauro, cujas miradas voltaram-se para a temática dos ambientes rurais (Galvão, 2004).

Em suas três décadas de funcionamento, o INCE manteve-se vinculado ao Ministério da Educação e Saúde ${ }^{10}$, sendo responsável pela produção de aproximadamente 500 títulos, compondo um amplo acervo de cinema educativo. As temáticas abordadas giravam em torno da divulgação científica brasileira, as ciências da natureza, as artes e os filmes de divulgação e publicidade do governo federal,

9 Trecho de transcrição do vídeo do INCE acerca da fala do Ministro da Educação e Saúde na época, Gustavo Capanema Filho, ao recepcionar as instalações da Rádio Sociedade. Disponível em: http://bases.cinemateca.gov.br/cgi-bin/wxis.exe/ $\mathrm{iah} /$ ? IsisScript=iah/iah.xis\&base=FILMOGRAFIA\&lang=p\&nextAction=lnk\&expr Search=ID=008246\&format=detailed.pf. Acesso em: 5 jan. 2019.

10 Em 1936 áreas temáticas como Saúde e Educação compunham a mesma pasta governamental. Somente em 1953 que é criado o Ministério da Saúde, sendo desmembrado, portanto, do Ministério da Educação e Saúde. 
tais como, inaugurações de obras públicas e cenas de atividades governamentais ${ }^{11}$. Apesar de atravessar um contexto político de grande instabilidade democrática - característica do século XX, em especial, no Brasil - , o INCE desempenhou suas atividades na composição e criação de imagens em movimento ${ }^{12}$ para serem distribuídas nas escolas de modo a abranger todo o território nacional. Interessante notar, ao longo dos processos históricos, que todo governo autoritário além de incentivar, geralmente costumava controlar a produção cinematográfica, linguagem geralmente empregada no delineamento de amplos projetos políticos educacionais.

\section{A PASSAGEM DA TV EDUCATIVA PARA A TV ESCOLA}

A partir de novembro de 1975, a missão da política pública voltada para o audiovisual educativo deslocou-se para a televisão por meio da consolidação da TV Educativa do Rio de Janeiro, TVE Brasil ou ainda TVE RJ, conforme anteriormente mencionado. Precursora na produção de conteúdos para a educação a distância, a concessão para a TVE aconteceu ainda em 1952, via Decreto no 30.832 (Brasil, 1952), sob a gestão da mesma concessionária da Rádio Emissora Roquette-Pinto (Rosa, 2015). Nesse período também surgiram outros canais de televisão com finalidades educativas, além de emissoras com conteúdos educativos pertencentes a instituições de ensino pelo país, tais como, a Fundação João Batista do Amaral (1955); a TV da Universidade Federal de Santa Maria (1958); a TV Universitária de Pernambuco (1967); e a TV Cultura (1969) (Rosa, 2015). Percebe-se que a década de 1960 urdiu-se, sobretudo, na consolidação das atuais tevês educativas. Dentre as famosas programações encontram-se o Sitio do Pica-Pau Amarelo, Pluft, o Fantasminha e a série $A$ Conquista, direcionadas para estudantes.

O projeto da TV Educativa foi encerrado em 2007, quase quarenta anos após sua criação, durante o governo do presidente Luís Inácio Lula da Silva (2003-2011). No entanto, esse projeto foi incorporado à Empresa Brasil de Comunicações e parte de sua programação migrou para a TV Brasil. Nessa época, a TV Escola, canal de televisão criado em 1996 e que já possuía dez anos de funcionamento, ganhou centralidade como política pública educacional do MEC, entretanto não no formato de publicidade governamental, mas pela disponibilização e circulação de conteúdos relativos às diversas áreas do saber.

11 Com base no Catálogo de filmes produzidos pelo INCE (1990), Sheila Schvarzman (2000) realizou um levantamento acerca do repertório temático produzido pelos cineastas do INCE, destacando 15 temas recorrentes. Para mais informações ver anexo II "Filmes por temáticas" (Schvarzman, 2000, p. 443).

12 Utilizamos o conceito de imagens em movimento como àquelas análogas ao cinema, conforme apresenta Gilles Deleuze (2018, p. 18): "Mas, na verdade, as condições determinantes do cinema são as seguintes: não apenas a foto, mas a foto instantânea (a fotografia pousada pertence a uma outra linhagem); a equidistância dos instantâneos; a transferência dessa equidistância para um suporte que constitui um 'filme' [...]. É nesse sentido que o cinema é o sistema que reproduz o movimento em função do instante qualquer, isto é, em função de momentos equidistantes, escolhidos de modo a dar a impressão de continuidade". 
Antes de abordarmos propriamente a criação da TV Escola, gostaríamos de destacar três acontecimentos contemporâneos ao seu surgimento que, ao estabelecerem a audiovisualidade ${ }^{13}$ como linguagem fulcral do que significa ensinar e aprender nos dias atuais, adensaram e adensam cada vez mais o espectro da sociedade educativa.

O primeiro deles diz respeito ao relatório para a Organização das Nações Unidas para a Educação, a Ciência e a Cultura (UNESCO), elaborado pela Comissão Internacional sobre Educação para o século XXI (1996), chamado Educação: um tesouro a descobrir, cujo relator foi o ex-presidente da Comissão Europeia, no período entre 1985 a 1995, o francês Jacques Delors. No capítulo IV desse documento são apresentados os pilares da educação: "aprender a conhecer"; "aprender a fazer"; "aprender a viver juntos"; "aprender a viver com os outros"; e, por fim, "aprender a ser".

O futuro destas economias depende, aliás, da sua capacidade de transformar o progresso dos conhecimentos em inovações geradoras de novas empresas e de novos empregos. Aprender a fazer não pode, pois, continuar a ter o significado simples de preparar alguém para uma tarefa material bem determinada, para fazê-lo participar no fabrico de alguma coisa. Como consequência, as aprendizagens devem evoluir e não podem mais ser consideradas como simples transmissão de práticas mais ou menos rotineiras, embora estas continuem a ter um valor formativo que não é de desprezar. (Delors et al., 1998, p. 93)

Ao destacar que o papel da educação nesse novo período conecta-se à sociedade do conhecimento, a aprendizagem volta-se para a inovação e a tecnologia será, sobretudo, o centro desse novo paradigma, cujo mote é a desescolarização. Esta, nos dizeres de Júlio Groppa Aquino (2017), possuiria duas linhagens discursivas que, segundo o autor, não têm sido problematizadas. A primeira diz respeito àquela defendida pelo austríaco Ivan Illich, para o qual

tudo se resumiria a um movimento cada vez mais centrífugo da ação educacional, doravante apoiada em redes de aprendizagem, isto é, em iniciativas não mais circunscritas ao formato escolar clássico e seus expedientes tidos como redutores da complexa decodificação do mundo, possibilitando, assim, que a função pedagógica fosse absorvida - e, com isso, hipertrofiada - por um sem-número de práticas espraiadas pelo tecido social. (Aquino, 2017, p. 672)

A segunda linhagem circunscreve-se em torno do brasileiro Paulo Freire, para o qual a escola precisaria reconquistar o seu papel político que consistiria

13 Trata-se de um neologismo criado por nós com a finalidade de considerar esse substantivo um tipo de manifestação do modo de viver a contemporaneidade por meio da feitura (quase adicta) de audiovisuais. Gonçalves (2020) forjou, por sua vez, o verbo-neologismo "audiovizualizar". 
de um realinhamento centrípeto do ensino, ainda no âmbito escolar, doravante imbuído de uma intencionalidade emancipatória e alicerçado em uma inquirição constante dos apelos de classe típicos da sociedade capitalista, os quais teriam nas narrativas escolares e nas relações entre seus protagonistas um continente de expressão ou, como quer Freire, de transformação. (Aquino, 2017, p. 672)

No mesmo ano de lançamento do relatório da UNESCO, houve, no Brasil, a regulamentação da Lei de Diretrizes e Bases da Educação Nacional (LDBEN) 9.394 (Brasil, 1996), traçando as normativas da política nacional de educação para o país. No título I, $D a$ Educação, Artigo I, o texto é enfático ao asseverar que os processos educativos envolvem todos os ciclos de sociabilidade do sujeito:

A educação abrange os processos formativos que se desenvolvem na vida familiar, na convivência humana, no trabalho, nas instituições de ensino e pesquisa, nos movimentos sociais e organizações da sociedade civil e nas manifestações culturais. (Brasil, 1996)

No Inciso II desse mesmo artigo, lê-se: "a educação escolar deverá vincular-se ao mundo do trabalho e à prática social" (Brasil, 1996). Nesse cenário de mudanças normativas e de recomendações multilaterais, a TV Escola é instituída então em 1996. Três anos depois, em 1999, no governo do presidente Fernando Henrique Cardoso, foi criado e implementado o Programa Sociedade da Informação (Socinfo), com o intuito de promover a sociedade do conhecimento no Brasil por meio dos eixos educação, telecomunicações e investimentos. Concernente à educação, o programa destacava o papel da TV Escola na promoção da educação a distância (Takahashi, 2000).

Desde sua implementação, a TV Escola ficou alocada na pasta do MEC, sob os cuidados da Secretaria de Educação a Distância (SEED) que, ao elaborar o relatório de avaliação do programa (Brasil, 2002), garantiu à TV Escola integrar parte de um conjunto de ações voltadas à democratização da educação básica, objetivando elevar a qualidade da educação. Sobre os princípios gerais norteadores do programa assevera-se que são os mesmos já delineados pela SEED (Brasil, 2002), isto é, "tecnologias a serviço da educação, integração e convergência entre diferentes tecnologias e formação de um leitor crítico e criativo". Já os objetivos específicos chamaram-nos a atenção. Dentre eles, destacam-se: "implementar uma proposta de pedagogia da imagem, que se caracteriza pelo uso da imagem não como simples ornamento, mas como uma forma de linguagem, de comunicação, gerando leitura, decodificação, descoberta, aprendizagem” (Brasil, 2002, p. 8, grifo nosso). Além disso, é enaltecido, nesse mesmo relatório, que o uso de vídeos educativos como fator gerador de conhecimento, instigando o aluno a pensar e a se expressar diferentemente, requer o emprego de recursos imagéticos no processo de ensino e aprendizagem. Observa-se, por meio desses documentos, a circulação dos discursos, ditos oficiais, acerca das sociedades da aprendizagem e sua instrumentalização normativa via implementação da TV Escola. 
O canal TV Escola, contemporâneo a esses três acontecimentos, foi regulamentado em 1996, tornando-se, após o fim da TV Educativa, a principal plataforma de conteúdos audiovisuais do MEC, tanto que em seu website lê-se: "A TV Escola não é um canal de divulgação de políticas públicas da educação, é uma política pública em si, com o objetivo de subsidiar a escola e não substituí-la”. Como o INCE, a TV Escola tem parte de seu acervo disponibilizado no Portal de Domínio Público do MEC e os conteúdos atuais são ofertados na plataforma online da TV Escola.

Ao analisar a TV Escola, Rondon Marques Rosa (2015) afirma que, desde sua criação, o referido canal é de uso exclusivo das escolas, ofertando desde equipamentos, como, antenas parabólicas, a televisões e materiais para gravação. Conforme ressalta o autor, a criação da TV Escola esteve em conformidade com os objetivos propostos pela Conferência Mundial de Educação para Todos, evento realizado em Jomtien, na Tailândia, em 1990, promovido pela UNESCO, pelo Programa das Nações Unidas para o Desenvolvimento (PNUD) e pelo Banco Mundial, visando ampliar todos os meios, especialmente as mídias, para o acesso à educação básica.

Um dos aspectos que salta aos olhos quando visitamos o website da TV Escola é a similaridade na disposição de conteúdos com outros streamings como Netflix, PopCorn time, Globo Play etc., que, para além do formato, as cores e as ferramentas para busca de conteúdos são idênticas. Entre as opções têm-se: animações, documentários, séries, reality shows, variedades, filmes, esportes, especiais e músicas que circulam em todo o território nacional, ao menos nos municípios aparelhados com conexão de internet banda larga. Convém lembrar que desde o ano de 2018, foram encerradas as transmissões de canais televisivos analógicos, vigorando somente as transmissões de canais via sinal digital e plataforma na internet.

Tanto o INCE quanto os canais da TV Educativa e da TV Escola foram atravessados pelas transformações das mídias audiovisuais e, mais recentemente, pelos conteúdos disponibilizados em plataformas online. Tais artefatos audiovisuais tornaram-se fulcrais nesse estudo, pois consideramos como problema central da contemporaneidade a emergência e o desenvolvimento de uma sociedade educativa audiovisualizada, como já mencionado. Desse modo, pode-se afirmar:

Se a Modernidade se inaugurou nos séculos XVI e XVII como "sociedade do ensino", hoje se estaria fechando sob a forma de uma "sociedade da aprendizagem", e teríamos, assim, uma grande virada: da ênfase inicial no "ensino" e na "instrução" para a ênfase na "aprendizagem" e, simultaneamente, da "Didática" para as "tradições pedagógicas". (Noguera-Ramírez, 2011, p. 230)

Tal ruptura parte da compreensão sobre a formação do Estado republicano brasileiro em fins do século XIX e da expansão do pensamento liberal. $\mathrm{Na}$ esteira dessas mudanças políticas e sociais, outro modus operandi passou a compor nossa experiência discursiva sobre a aprendizagem, instituindo como ponto nodal desse processo o próprio indivíduo, regulador de si e do conhecimento que pretende adquirir.

Compreendemos que estamos sujeitados a uma governamentalidade visual cujos efeitos reverberaram em abordagens pedagogizantes chamadas de: apren- 
dizagem por competência, aprendizagem contínua, dentre outras denominações equivalentes. Concebendo governamentalidade como o governo de si, dos outros e dos sujeitos entre si (Foucault, 2008), a governamentalidade visual atravessa o ensino e a aprendizagem sob a apologia do emprego de imagens, especialmente aquelas em movimento. E talvez seja na Modernidade, com João Amós Comênio ${ }^{14}$, que verificamos a forja de uma pedagogia da imagem. Como salienta Georges Didi-Huberman (2017, p. 188):

É em 1658 que a cartilha ilustrada conhece seu momento de fundação com o Orbis sensualium pictus, de Comenius, obra ilustrada com 150 figuras, tão popular que foi constantemente reeditada até o início do século XIX. A época das luzes verá - a partir, sobretudo, das reflexões conduzidas por Jean-Jacques Rousseau, em 1762, em Émile ou de l'éducation - um desenvolvimento considerável da literatura infantil e da pedagogia pela imagem.

Isso posto, é possível constatar que a linguagem do audiovisual, particularmente a linguagem cinematográfica, está presente nas ambiências escolares há quase um século e, nos dias atuais, também adentrou as salas de aulas dos cursos de graduação em licenciatura brasileiros, voltados para a formação de professores (Oliveira Júnior e Martins, 2011; Brasil, 2014; Kerr Júnior, 2014; Pinheiro, 2014; Leite, 2013; Azevedo, Ramírez e Oliveira Júnior, 2015a, 2015b; Gonçalves e Cazetta, 2017). Outrossim, a forte entrada do cinema nas escolas e universidades brasileiras também tem sido assegurada, nos dias atuais, pelo Plano de diretrizes e metas para o audiovisual: o Brasil de todos os olhares para todas as telas (PDM 2013), no qual há o detalhamento de metas a serem cumpridas pelo setor audiovisual até o ano de 2020 (ANCINE, 2013). A última meta trata novamente da aproximação do setor audiovisual com o MEC, de modo que a Lei no 13.006 (Brasil, 2014), sancionada em 26 de junho de 2014 pela presidente Dilma Rousseff, já é uma evidência dessa aproximação, ao tornar obrigatória a exibição de, no mínimo, duas horas mensais de filmes nacionais nas escolas.

A partir dos anos 2000 houve uma profusão de textos acadêmico-científicos acerca da fronteira entre cinema e educação. Nesses estudos constatamos três tendências. A primeira diz respeito ao emprego instrumental do cinema, tanto na escola quanto na formação de professores. Instrumental no sentido de uma "didatização" do filme, isto é, "há uma indicação de filmes que são bons para discutir isso ou aquilo, ou que trazem essa ou aquela reflexão" (Leite e Christofoletti, 2015, p. 43). A segunda refere-se a uma série de críticas encontradas no livro organizado por Adriana Fresquet (2015), no ano seguinte à publicação da Lei no 13.006/2014, constituído por 20 trabalhos sistematizados por 40 profissionais, entre professores e pesquisadores vinculados a grupos de pesquisa de diversas universidades brasileiras, professores de educação básica, e cineclubistas, que operam na suprarreferida fronteira. E, por fim, a terceira tendência de estudos, cujos autores advogam em prol

14 Nome aportuguesado do latim Iohannes Amos Comenius. 
de uma abordagem política e poética da linguagem cinematográfica, no sentido de que "um cinema que 'educa'é aquele que nos (faz) pensar - e que (nos) faz pensar não somente sobre o cinema em si mesmo, mas, igualmente, sobre 'as mais variadas experiências e questões que ele coloca em foco"' (Xavier, 2008, p. 14).

\section{A DESMONTAGEM DAS ANIMAÇÕES}

\section{$\mathrm{H}_{2} \mathrm{O}$ : UMA PRODUÇÃO DO INCE}

Analisaremos os efeitos da sociedade da aprendizagem em duas animações do arquivo audiovisual selecionado, verificando o sujeito que enuncia, de onde enuncia e para quem enuncia. A análise tende a considerar o deslocamento e a flexibilização dos espaços geográficos institucionais que se sobrepuseram a todas as outras ambiências a despeito de não serem espaços, ambientes ou objetos, supostamente adequados para ensinar e aprender. $\mathrm{Na}$ sociedade da aprendizagem a autorregulação e o audiovisual tornaram-se quase que prerrogativas das espacialidades urbanas.

Datada de 1962 e dirigida por Guy Lebrun, $\mathrm{H}_{2} \mathrm{O}$, com duração de 5 minutos e 33 segundos, foi uma animação produzida pelo Studios de Desenhos Animados Guy para o INCE (Figura 1A). Direcionada para o ensino de ciências da natureza, especialmente química, $\mathrm{H}_{2} \mathrm{O}$ aborda os estados líquido, sólido e gasoso da água. Todavia, a animação inicia com a seguinte apresentação: "De acordo com o que dispõe o parágrafo único do artigo $5^{\circ}$ do Decreto $20.493^{15}$ da Lei no 1.949 de 1939 , este filme está isento de censura" (Brasil,1939). Segundo o Cap.5० do mesmo Decreto, estariam isentos pelo Serviço de Censura e Diversões Públicas (SCDP), órgão pertencente ao Departamento de Segurança Pública do governo federal, os filmes produzidos pelo INCE e demais órgãos oficiais do governo (Figura 1B). Interessante ler no Art. 21 desse decreto o que se concebia como cinema educativo: "Os filmes que divulguem conhecimentos instrutivos, morais ou artísticos, ou contribuam, de diversas maneiras, para aprimorar a formação espiritual, a educação social e o valor intelectual ou artístico da assistência" (Brasil, 1939). No artigo seguinte, o de número 22, são expressas recomendações acerca dos conteúdos fílmicos a serem produzidos: "Filmes capazes de despertar os bons sentimentos, as tendências artísticas, a curiosidade científica, o amor à pátria, à família e o respeito às instituições"(Brasil,1939). Após a apresentação institucional, começa a animação (Figura 1C), cujas formas de falar e de fazer falar, de ver e de fazer ver dos frames são aquelas relativas à voz do Estado brasileiro na sua função de instrutor. Quem diz e permite dar a ver é o Estado brasileiro por meio de sua capacidade de censurar o que é educativo. Ressaltamos que o presidente do Brasil, em 1962, era João Goulart, que se pautava por um regime democrático de grande participação popular, antecedendo o golpe civil militar.

15 Decreto que aprovou o regulamento do Serviço de Censura de Diversões Públicas do Departamento Federal de Segurança Pública. Disponível em: https://www2.camara. leg.br/legin/fed/decret/1940-1949/decreto-20493-24-janeiro-1946-329043-publicacaooriginal-1-pe.html. Acesso em: 5 jun. 2019. 

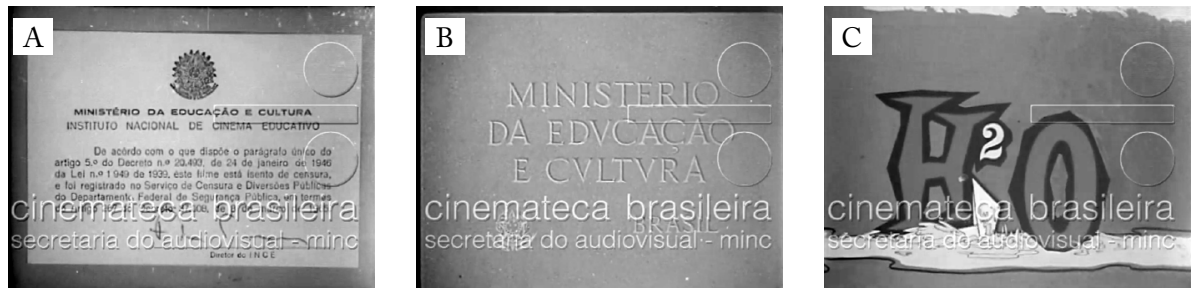

Fonte: disponível no Banco de Conteúdos Culturais do website da Cinemateca Brasileira (1962).

Figura 1 - (A, B e C) Fotograma de abertura da animação $\mathrm{H}_{2} \mathrm{O}$.

O ano de 1962 marcou o início da escassez do INCE na produção de curtas-metragens de animação, lembrando que, dois anos antes, em 1959, intelectuais lançaram o segundo manifesto pela educação nacional, alicerçado no Manifesto dos Pioneiros da Educação Nova, de 1932, chamado "Manifesto dos educadores: mais uma vez convocados"16, assinado por dezenas de intelectuais como Fernando de Azevedo, Florestan Fernandes, Ruth Correia Leite Cardoso, Cecília Meireles entre outros. Há nesse novo Manifesto, além de uma análise da situação educacional, quais seriam as tarefas e as atribuições do Estado na garantia de um projeto nacional de educação. Helena Bomeny Garchet afirma, por meio de nota publicada no website do Centro de Pesquisa e Documentação de História Contemporânea do Brasil (CPDOC), que Jango, ao assumir a presidência do Brasil em 1961, fica estarrecido com o panorama educacional do país: "uma população de 70.779 .352 habitantes, com $39,5 \%$ de analfabetos, distribuídos nas faixas etárias entre 15 e 69 anos" (Bomeny, 2010).

$\mathrm{Na}$ desmontagem de $\mathrm{H}_{2} \mathrm{O}$ é evidenciada sua superfície discursiva: a presença do Estado por meio da institucionalidade legal, ou seja, o decreto e, logo depois, a inscrição do Ministério da Educação e Saúde, anunciando que o filme cumpre todos os requisitos legais.

O roteiro da animação diz respeito à explicação dos estados da água para o personagem Joãozinho (Figura $2 \mathrm{~A}$ ). Em um ambiente com características rurais e acompanhado de um balde de água, o menino, com idade aproximada de oito anos e, provavelmente, indo realizar alguma tarefa, é abordado no caminho por uma voz masculina externa que o indaga: "Hei, Hei Joãozinho. Onde vamos com esse balde? Buscar água? Aliás, Joãozinho, você sabe o que é a água?”. Logo que ele é abordado por essa voz, similar a de um locutor de rádio da voz institucional do Programa Voz do Brasil ${ }^{17}$, Joãozinho prontifica-se a escutá-la (Figura 2B). Ao interagir com o ambiente de acordo com as transformações

16 Disponível em: https://www.fe.unicamp.br/pf-fe/publicacao/4922/doc2_22e.pdf. Acesso em: 26 maio 2019.

17 Ainda realizando transmissão, trata-se do programa de rádio mais antigo do Brasil. Criado em 1935, durante o governo de Getúlio Vargas, esse noticiário radiofônico estatal, de difusão obrigatória nas estações de rádio e com duração de uma hora, é produzido pela Empresa Brasileira de Comunicação (Wikipedia, 2019). 

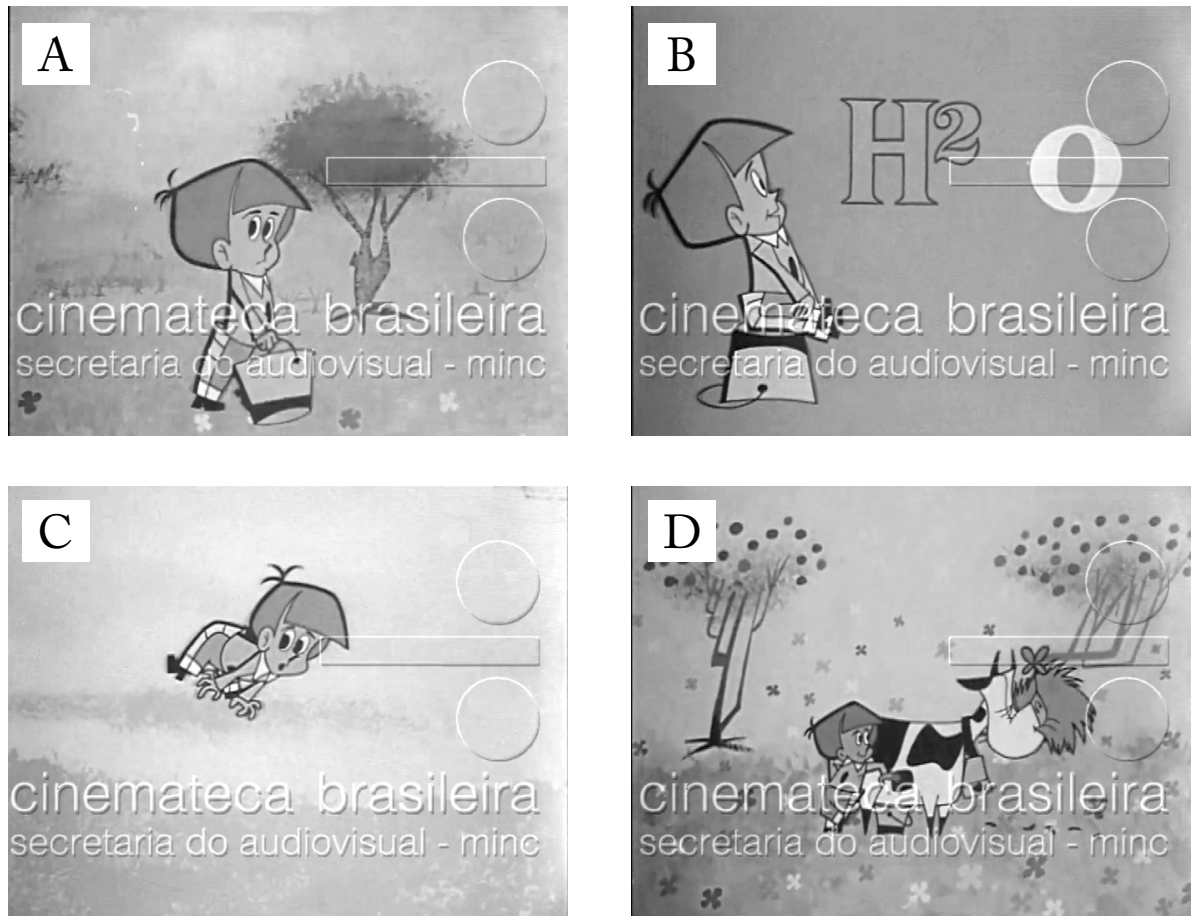

Fonte: disponível no Banco de Conteúdos Culturais do website da Cinemateca Brasileira (1962).

Figura 2 - (A, B, C e D) Fotogramas da animação $\mathrm{H}_{2} \mathrm{O}$.

da água, ele não enuncia uma palavra sequer; sua interação acontece apenas por meio da gestualidade, demonstrando atenção à explicação dada pela voz institucional. Nesse frame, tem-se a voz da instrução, a voz disciplinar de um suposto professor. Esse corte na desmontagem é como um torvelinho arrastando nossa memória para uma experiência do "dito/falado" daquele que ensina: "A água potável é a que é boa pra beber. Normalmente a água é encontrada em estado líquido. Cuidado Joãozinho! Porque ela pode ser encontrada em estado sólido e aí chama-se gelo".

Joãozinho, o protagonista, além de não evidenciar nenhum discernimento, também não possui nenhuma experiência acerca dos estados físicos da água, por isso cada mudança do estado dessa matéria resulta constrangedor para ele. $\mathrm{Na} \mathrm{Fi-}$ gura 2C, Joãozinho estatela-se no gelo, demonstrando ingenuidade e ausência de qualquer repertório cultural sobre o tema da água.

Nas cenas seguintes que finalizam a animação, percebe-se uma alteração na entonação da voz institucional: "A água é indispensável à vida, sem água não pode haver vida animal, nem vegetal na Terra [...]. Pronto, pode ir sossegadamente encher seu balde, mas espera Joãozinho. Aonde vai você? A água está aqui homem!". Após 
essa intervenção Joãozinho vai em busca de leite e, em seguida, ordenha ${ }^{18}$ manualmente uma vaca (Figura 2D), atividade incomum nos dias de hoje, especialmente para uma criança de oito anos, como é o caso de Joãozinho. Porém, a voz externa diz: "Hum, estou vendo, mas a lição não foi perdida, não é Joãozinho? Mesmo porque o leite, além do leite ser líquido, tem grande porção de água. Então, sobre a água você já sabe tudo, não é Joãozinho?”.

Ao final da animação não é possível inferir se Joãozinho entendeu a explicação sobre $\mathrm{H}_{2} \mathrm{O}$, entretanto a "lição não foi perdida", ou seja, mesmo que ele não tenha entendido a lição, o Estado, por meio de sua voz professoral, cumpriu seu papel de instruir o pequeno Joãozinho.

Debruçar-nos-emos agora sobre a série "De onde Vem?”, especialmente o episódio De Onde Vem O Fósforo? Com duração de 4 minutos e 17 segundos, esse episódio foi produzido em 2002 pela TV Escola e pela TV Pinguim, também direcionado para o ensino de ciências da natureza.

\section{DE ONDE VEM O FÓSFORO?: UMA PRODUÇÃO DA TV ESCOLA E DA TV PINGUIM}

Diferente da primeira animação, De onde vem o fósforo? não possui censura, nem logomarca oficial do MEC; o logotipo da TV Escola aparece somente na parte superior esquerda do enquadramento de abertura (Figura 3A). Aqui há dois protagonistas: a garota Kika e o palito de fósforo. De estilo mais despojado, Kika é apresentada à pergunta "De onde vem?" e, em seguida, ao palito de fósforo (Figura 3B), que se trata do "professor" da garota. Kika também possui em torno de oito anos de idade, conforme descrito na sinopse do episódio.
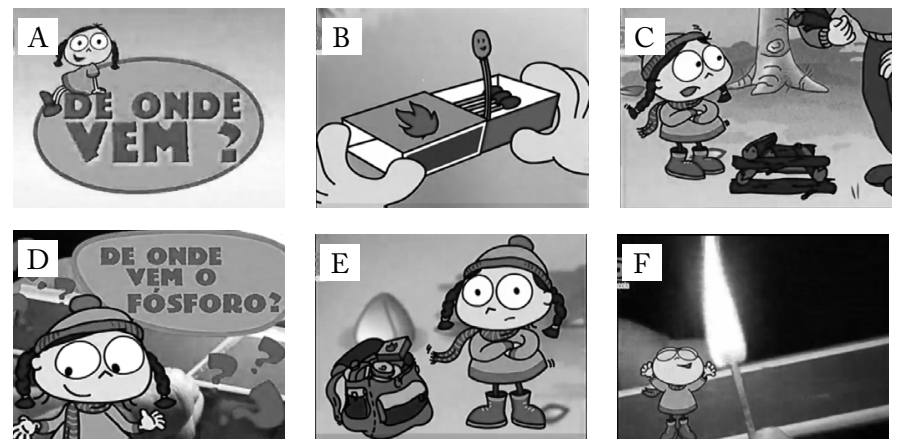

Fonte: disponível no Banco de Conteúdos Culturais do website da Cinemateca Brasileira (2019).

Figura 3 - (A, B, C, D, E e F) Fotogramas da animação De onde vem o fósforo?

O enredo dessa animação desenvolve-se em torno de uma floresta, onde Kika e seu pai, prestes a acender uma fogueira, solicita à filha para pegar um palito de fósforo. Nesse instante, Kika questiona-o: "Mas ué, de onde vem o fósforo?".

18 Para mais informações sobre ordenha ver: https://pt.wikihow.com/Ordenhar-uma-Vaca. Acesso em: $1^{\mathrm{o}}$ jun. 2019. 
Diante da interpelação da filha, o pai responde: "Lá da minha mochila, filhinha". $\mathrm{E}$, num gesto de contestação, a garota diz: "É fogo, ninguém entende as minhas perguntas!”. Podemos visualizar a sequência dos diálogos nas Figuras 3C, 3D e 3E.

Interessante notar, na Figura 3C, que o adulto, nesse caso o pai da Kika, aparece sem a porção superior do corpo; vale destacar que em todos os outros episódios seus pais aparecem dessa perspectiva. Os adultos não possuem nenhum destaque visual e verbal na animação, pois, além de não possuírem a porção superior do corpo, respondem de forma insatisfatória às interpelações de Kika, demonstrando pouco interesse aos questionamentos dela acerca do mundo que a circunda.

Diferente de $\mathrm{H}_{2} \mathrm{O}$, na qual Joãozinho não questiona a voz superior, Kika, ao contrário, indaga os pais, seu entorno e os objetos à sua volta, problematizando, inclusive, a naturalização das coisas pelos adultos. Ou seja, Kika inquire a voz superior que a instrui! A garota possui a competência de transformar suas experiências, tributárias do universo infantil, em possibilidades de aprendizagem. Ela já "aprendeu a aprender" e possui uma capacidade investigativa quase inata.

Ao perceber a frustração da garota com a resposta do pai, o palito de fósforo (Figuras 3F e 3G) salta da caixa e responde: "Eu entendo, Kikinha. Vou te contar a minha história...”. Desse momento em diante, o palito enunciador narra desde sua própria invenção até a origem do fogo, com cortes e detalhes sobre essa cronologia.

Quando a haste de madeira termina de ensinar Kika sobre o fósforo, ela, exuberante, explica ao pai a origem do fósforo e do palito de fósforo. Recuperamos na íntegra esse trecho da animação:

Não esquenta pai, está aqui o palito que é feito de madeira. E que tem a cabeça de cloreto de potássio. E que fica em uma caixinha com uma listinha que tem o elemento fósforo. Agora você lixa o palitinho na lixa da caixinha e produz uma chama que queima a lenha e acende a fogueira. E esquenta a sua filhinha. (De Onde Vem O Fósforo?, 2019)

Surpreso, o pai interroga: "Nossa Kika! De onde você tirou essas informações tão quentes?”. E Kika responde: “Se eu contar você não vai acreditar!”. A seguir, a animação é finalizada com a personagem Kika despedindo-se diretamente daqueles que, supostamente, estão assistindo a animação.

\section{QUARENTA E DOIS ANOS DEPOIS: O ENCONTRO ENTRE O INCE E A TV ESCOLA}

O salto de 42 anos entre uma animação e outra evidencia os deslocamentos discursivos textuais e visuais das duas animações. Na primeira, Joãozinho aprende por intermédio da voz interlocutora; na segunda, Kika aprende com a voz interlocutora de um palito de fósforo, tributário da ambiência na qual a personagem está inserida. Em outros episódios da série "De onde vem?", a menina aprende com o vidro, o ovo, a onda, o arco-íris e tantos outros objetos. Isso reforça o argumento de Noguera-Ramírez (2011), qual seja, que o meio social e não mais somente o espaço institucional da escola, tornaram-se lugares de aprendizagem. Assim, 
Manipular o meio, acondicionar o meio, preparar o ambiente em função de suas possibilidades educativas - essa é a nova tarefa do preceptor. Sua ação, oposta à ação didática, não deve ser direta; ele deve intervir, mas só através do meio, pois quem melhor ensina são as coisas e a natureza. Nesse sentido, pode-se dizer que a educação é uma espécie de autorregulação, e não um disciplinamento, isto é, a ação do indivíduo em um meio (natural, artificial, ou social) cujo resultado é o seu crescimento, seu desenvolvimento, sua manutenção e sua aprendizagem. (Noguera-Ramírez, 2011, p. 165)

No caso da primeira animação, Joãozinho aprende com a ambiência rural onde vive, porém sem autonomia e protagonismo concernente àquilo que escuta. É como uma tábula rasa ${ }^{19}$, cujo corpo está pronto para ser instruído. Esse tipo de autonomia, chamado de autorregulação (Noguera-Ramírez, 2011), também compreendido como governo interior ou governo da alma (Rose, 1988), é que possibilita a forja de sujeitos que consigam governar as próprias experiências, transformando-as em possibilidades educativas. Nessa formulação o poder institucional desloca-se do instrutor, daquele que ensina, para a interioridade do sujeito. Se anteriormente os processos de ensino e aprendizagem aconteciam por meio da força institucional no corpo das pessoas, na sociedade da aprendizagem esse poder se institui dentro desses corpos, que se tornaram reguladores de si. Ou seja, "o poder não só produz os limites do sujeito, mas também permeia sua interioridade" (Butler, 2017, p. 96). Nessa acepção, não é necessário desfazer o poder da instituição sobre os corpos, mas implicá-lo no governamento de cada indivíduo sobre sua própria experiência da aprendizagem, isto é, em um governo de si, dos outros e dos sujeitos entre si.

A personagem Kika conduz seu processo de aprendizagem sem necessidade da ambiência escolar porque está sujeitada a se autorregular, ao mesmo tempo que está "sujeitando-se a um poder, uma sujeição que implica uma dependência radical" (Butler,2017, p. 89). O corpo e sua interioridade são forjados, então, por uma matriz discursiva da aprendizagem contínua, agente da sociedade da aprendizagem. Esse processo de sujeição se constitui sobre os corpos dos indivíduos via tecnologias educativas, nesse caso, nas animações veiculadas para o público em idade escolar.

Não é apenas uma relação exterior entre o objeto (animação) e o sujeito (estudante), "pelo contrário, o indivíduo se forma - ou melhor, formula-se - como prisioneiro por meio de sua 'identidade' constituída discursivamente”(Butler, 2017,p. 90). Essa identidade de aprendiz contínuo com capacidades investigativas apresenta um deslocamento na ideia de disciplina, que regulariza e normatiza os sujeitos, de maneira que, na contemporaneidade, o sujeito não necessita da voz instrutora que o regulariza, afinal, a disciplina já está contida nele.

A sociedade disciplinar por nós forjada, e da qual somos parte constituinte, é formada por "instituições, procedimentos, análises, reflexões, cálculos, táticas que permitem exercer essa forma bastante específica e complexa de poder" (Foucault,

19 Expressão que significa que uma pessoa é como uma folha de papel em branco, ou seja, sem conteúdo e pronta para ser instruída. 
2013b, p. 429). Portanto, a sociedade disciplinar sobrepõe-se à sociedade educativa que tem, por sua vez, nas políticas audiovisuais educativas, a regulação das crianças e adolescentes. A disciplina pedagógica está presente tanto em Kika como em Joãozinho, porém com deslocamentos exteriores (da espacialidade institucional) e interiores (para o próprio corpo do indivíduo).

Dessa forma, não podemos reduzir o papel do Estado apenas às funções de gestão e controle da máquina pública e do desenvolvimento das forças produtivas e econômicas (Foucault, 2013b), mas compreender que desde a modernidade e por meio do liberalismo econômico "vivemos na era da governamentalidade" (Foucault, 2013b, p. 430). Para o autor, a governamentalidade permite ao Estado ser o que ele é, ou seja, governamentalizado e, ao mesmo tempo, governar os sujeitos entre si por meio de suas táticas como, no caso desse texto, da implementação das políticas públicas audiovisuais educativas. O Estado constitui-se quando a população se governa por intermédio do governo dos indivíduos em si, pelo governo dos indivíduos entre os próprios indivíduos e o governo dos outros.

Interessante perceber que em nenhuma das animações o ambiente institucional escolar é visibilizado; os personagens aprendem e apreendem as coisas do mundo mediante suas experiências no meio social. Essa constatação é um dos principais deslocamentos forjados na sociedade da aprendizagem: a flexibilização da ambiência da aprendizagem que torna qualquer espaço, local apropriado para o sujeito aprender, seja pela via da curiosidade, seja pela via do interesse, ou ainda pela via da motivação. Dessa forma, a dupla finalidade do audiovisual, seja como política pública educativa, seja como pedagogia de imagens em movimento, diz das características da sociedade da aprendizagem. Se as ambiências onde se pode aprender estão cada vez mais desterritorializadas, estas continuam a exigir o investimento na produção de corpos disciplinados, pois, para aprender em ambiências cujas espacialidades são moventes, é preciso disciplinar o corpo para que este possa autogovernar-se.

\section{CONSIDERAÇÕES FINAIS}

Os dois tipos de sujeito personificados em Joãozinho e Kika são a forja da própria sociedade da aprendizagem. Joãozinho não fala, é desprovido de linguagem, mas escuta a voz interlocutora. Esta, de natureza acadêmico-científica, conduz o enredo da animação, fazendo com que Joãozinho aprenda tanto com ela quanto com a ambiência rural, não escolarizada, por meio da execução de uma tarefa. A animação enuncia para o garoto do campo que ele é destituído de conhecimentos prévios sobre os estados físicos da água. Kika, ao contrário, aprende por meio de suas experiências ordinárias e, a partir do local no qual está inserida, é questionadora, direcionando suas perguntas para os adultos que não satisfazem suas indagações. No caso dessa animação quem enuncia é o palito de fósforo, o objeto que ela está manipulando, isto é, a voz da instrução pertence aos objetos do meio social. São eles que dizem o que ela deve aprender. Por último, devido aos cortes dos membros superiores dos adultos, percebe-se que a animação é direcionada para o público infantil mais amplo. 
Para que se possa aprender, mesmo em ambientes desterritorializados e não institucionalizados, é notável nas duas animações: a flexibilização do espaço institucional escolar; a manutenção da disciplina por meio da instrução de Joãozinho e da autonomia e protagonismo de Kika, que possui uma identidade questionadora; e a autorregulação da aprendizagem efetuada por Kika ao ter competências como "aprender a conhecer", "aprender a fazer", “aprender a viver juntos", "aprender a viver com os outros" e "aprender a ser".

Por fim destacamos que, mesmo ancoradas na sociedade da aprendizagem, as duas animações complexificaram-se por meio das seguintes conclusões: Alexibilidade das ambiências de aprendizagem, não sendo mais, como observado nas animações, a escola o lugar do aprender, mas o mundo e as coisas; o deslocamento da disciplina escolar, demandando que toda experiência de aprendizagem do sujeito seja contínua e por competências; e a autorregulação da aprendizagem, verificada nos dois curtas-metragens de animação, especialmente na personagem Kika ("De onde vem?") que, por sua competência em aprender com os objetos e as coisas, é diferente daquela do personagem Joãozinho (" $\mathrm{H}_{2} \mathrm{O}$ "). As três dimensões, a flexibilidade das ambiências, o deslocamento da ideia de disciplina e a autorregulação da aprendizagem são as táticas investidas (via audiovisuais) pelo MEC, as quais podemos caracterizar, então, como constituidoras de uma governamentalidade visual.

\section{REFERÊNCIAS}

AGENCIA NACIONAL DO CINEMA (ANCINE). Plano de diretrizes e metas para o audiovisual: o Brasil de todos os olhares para todas as telas. Rio de Janeiro: Agência Nacional do Cinema, 2013.

ANDRADE, R. O. Filmes na escola: Instituto Nacional de Cinema Educativo teve papel fundamental no ensino e na divulgação científica no Brasil. Revista Fapesp, São Paulo, n. 27, p. 83-87, set. 2018. Disponível em: https://revistapesquisa.fapesp.br/2018/09/18/filmesna-escola/. Acesso em: $1^{\circ}$ jun. 2019.

AQUINO, J. G. Defender a escola das pedagogias contemporâneas. Educação Temática Digital, v. 19, n. 4, p. 669-690, 2017. Disponível em: https://doi.org/10.20396/etd. v19i4.8648729. Acesso em: $1^{\circ}$ jun. 2019.

AZEVEDO, A. F.; RAMÍREZ, R. C.; OLIVEIRA JÚNIOR, W.M.(Org.). Intervalo I: entre geografias e cinemas. Braga: Editora da Uminho, 2015a. v. 1.734 p.

AZEVEDO, A. F.; RAMÍREZ, R. C.; OLIVEIRA JÚNIOR, W. M. (Org.). Intervalo II: entre geografias e cinemas. Braga: Editora da Uminho, 2015b. v. 2.353 p.

AZEVEDO, F. et al. O manifesto dos pioneiros da Educação Nova. Revista Brasileira de Estudos Pedagógicos, Brasília, v. 65, n. 150, p. 407-425, maio/ago. 1984. Disponível em: https://download.inep.gov.br/download/70Anos/Manifesto_dos_Pioneiros_Educacao_ Nova.pdf. Acesso em: 17 jun. 2021.

BOMENY, H. Na presidência da República: o sentido político da educação de Jango. FGV, 2010. Disponível em: https://cpdoc.fgv.br/producao/dossies/Jango/artigos/ 
NaPresidenciaRepublica/O_sentido_politico_da_educacao_de_Jango.Acesso em:26 maio 2019.

BRASIL. Decreto no 21.240, de 4 de abril de 1932. Brasil, 1932. Disponível em: http:// www2.camara.leg.br/legin/fed/decret/1930-1939/decreto-21240-4-abril-1932-515832publicacaooriginal-81522-pe.html. Acesso em: 30 maio 2019.

BRASIL. Decreto-Lei no 1.949, de 30 de dezembro de 1939. Decreto que dispõe sobre o exercício da atividade de imprensa e propaganda no território nacional e dá outras providências. Brasil, 1939. Disponível em: https://www2.camara.leg.br/legin/fed/ declei/1930-1939/decreto-lei-1949-30-dezembro-1939-412059-publicacaooriginal-1-pe. html. Acesso em: 26 maio 2019.

BRASIL. Decreto no 30.832, de 10 de maio de 1952. Brasil, 1952. Disponível em: https:// www.lexml.gov.br/urn/urn:lex:br:federal:decreto:1952-05-10;30832.Acesso em: 5 jun. 2019. BRASIL. Lei no 9.394, de 20 de dezembro de 1996. Brasil, 1996. Disponível em: http:// www.planalto.gov.br/ccivil_03/LEIS/L9394.htm. Acesso em: 4 fev. 2019.

BRASIL. Ministério da Educação. TV Escola: relatório 1996-2002. Brasília: Secretaria de Educação a Distância (SEED), 2002. Disponível em: http://portal.mec.gov.br/seed/ arquivos/pdf/tvescola/relatividades/TVEscola19962002.pdf. Acesso: 19 jan. 2019.

BRASIL. Lei no 13.006/2014, de 26 de junho de 2014. 2014. Disponível em: http://www. planalto.gov.br/ccivil_03/_Ato2011-2014/2014/Lei/L13006.htm. Acesso em: 28 maio 2018.

BRUZZO, C. Filme “ensinante": o interesse pelo cinema educativo no Brasil. Pro-Posições, v. 15, n. 1, p. 159-173, jan./abr. 2004.

BURCH, S. Sociedade da informação/sociedade do conhecimento. In: AMBROSI, A.; PEUGEOT, V.; PIMENTA, D. (Coord.). Desafios de palavras: enfoques multiculturais sobre as Sociedades da Informação. Caen-France: C \& F Éditions, 2005. Disponível em: http://www.dcc.ufrj.br/ jonathan/compsoc/Sally\%20Burch.pdf. Acesso em: 8 mar. 2019.

BUTLER, J. A vida psíquica do poder: teorias da sujeição. Tradução: Rogério Bettoni. Belo Horizonte: Autêntica, 2017.

CALABRE, L. Políticas culturais no Brasil: dos anos 1930 ao século XXI. Rio de Janeiro: Editora FGV,2009.

CAMARA, S. A Reforma Fernando de Azevedo e as Colmeias Laboriosas no Distrito Federal de 1927 a 1930. In: MIGUEL, M.; VIDAL, D. Reformas Educacionais: as manifestações da Escola Nova no Brasil (1920 a 1946). Campinas: Autores Associados; Uberlândia: EDUFU, 2011.p. 177-196.

CASTELLS, M. A sociedade em rede: do conhecimento à política. In: CASTELLS, M.; CARDOSO, G. (Org.). A sociedade em rede: do conhecimento à acção política. Lisboa: Imprensa Nacional/Casa da Moeda, 2006. p. 17-30. Disponível em: http://www.egov.ufsc. br/portal/sites/default/files/anexos/a_sociedade_em_rede_-_do_conhecimento_a_acao_ politica.pdf. Acesso em: 5 jun. 2019.

CATELLI, R.Dos “naturais” ao documentário: o cinema educativo e a educação do cinema entre os anos 1920 e 1930. 2007. 244f. Tese (Doutorado em Multimeios) - Universidade Estadual de Campinas, Campinas, 2007. 
DELEUZE, G. Cinema 1: A Imagem Movimento. Tradução: Eloisa Araújo Ribeiro. São Paulo: 34, 2018.

DELORS, J. et al. Educação: um tesouro a descobrir. Relatório para a UNESCO da Comissão Internacional sobre Educação para o século XXI. Tradução: José Carlos Eufrázio. São Paulo: Cortez: UNESCO no Brasil/MEC, 1998. Disponível em: http://dhnet.org. br/dados/relatorios/a_pdf/r_unesco_educ_tesouro_descobrir.pdf. Acesso em: 4 mar. 2019. DE ONDE VEM O FÓSFORO? Produção: TV Escola/TV Pinguim. Brasil, 2002. 1 vídeo (4 min $17 \mathrm{~s}$ ), son., color. Disponível em: https://tvescola.org.br/videos/de-onde-vemde-onde-vem-o-fosforo/. Acesso em: 5 jun. 2019.

DIDI-HUBERMAN, G. Quando as imagens tomam posição. Tradução: Cleonice Paes Barreto Mourão. Belo Horizonte: Editora da UFMG, 2017.

DISTRITO FEDERAL. Decreto no 2.940, de 22 de novembro de 1928. Regulamento do ensino. Prefeitura do Distrito Federal. Rio de Janeiro: Oficinas Gráficas do Jornal do Brasil, 1928.

DUARTE, N. As pedagogias do aprender a aprender e algumas ilusões da assim chamada sociedade do conhecimento. Revista Brasileira de Educação, Rio de Janeiro,n. 18, p.35-40, dez. 2001. Disponível em: http://www.scielo.br/pdf/rbedu/n18/n18a04.pdf. Acesso em: 6 fev. 2019. https://doi.org/10.1590/S1413-24782001000300004

FABELA, S. A vida toda para aprender. Portal dos Psicólogos,2005. Disponível em: http:// www.psicologia.pt/artigos/textos/A0321.pdf. Acesso em: 6 fev. 2019.

FOLHA DE S.PAULO. Manual da redação: as normas de escrita e conduta do principal jornal do país. 21. ed. São Paulo: Publifolha, 2018.

FOUCAULT,M. Segurança, território, população: curso dado no Collège de France (19771978). Tradução de Eduardo Brandão. São Paulo: Martins Fontes, 2008. (Coleção Tópicos).

FOUCAULT, M. A arqueologia do saber. 8. ed. Tradução: Luiz Felipe Baeta Neves. Rio de Janeiro: Forense Universitária, 2013a.

FOUCAULT, M. A governamentalidade. In: FOUCAULT, M. Microfísica do poder. 26. ed. São Paulo: Ed. Graal, 2013b. p. 407-431.

FREIRE, G. H. A. O trabalho de informação na sociedade do aprendizado contínuo. Informação \& Sociedade: Estudos, João Pessoa, v. 17, n. 3, p. 39-45, set./dez. 2007. Disponível em: http://www.brapci.inf.br/index.php/res/download/105676. Acesso em: 5 jun. 2019.

FRESQUET, A. (Org.). Cinema e Educação: A Lei 13.006 - Reflexões, perspectivas e propostas. Belo Horizonte: Universo Produção, 2015.

GADOTTI, M. Perspectivas atuais da educação. São Paulo em Perspectiva, São Paulo, v. 14, n. 2, p. 3-11, abr./jun. 2000. Disponível em: http://www.scielo.br/pdf/spp/v14n2/9782. pdf. Acesso em: 5 jun. 2019. https://doi.org/10.1590/S0102-88392000000200002

GALVÃO, E. A ciência vai ao cinema: uma análise de filmes educativos e de divulgação científica do Instituto Nacional do Cinema Educativo (Ince). 2004. 278f. Dissertação (Mestrado em Ciências) - Departamento de Instituto de Ciências Biomédicas, Universidade Federal do Rio de Janeiro, Rio de Janeiro, 2004. 
GASQUE, K. G. D.; TESCAROLO, R. Sociedade da aprendizagem: informação, reflexão e ética. Ciência da Informação, Brasília, v. 33, n. 3, p. 35-40, set./dez. 2004. Disponível em: https://doi.org/10.1590/S0100-19652004000300005. Acesso em: 5 jun. 2019.

GONÇALVES, I. R. Arquivo-vida na contemporaneidade: composições de modos de viver nas fronteiras entre audiovisual, arquivos pessoais e educação. 2020.215f. Dissertação (Mestrado em Educação) - Faculdade de Educação, Universidade de São Paulo, São Paulo, 2020.

GONÇALVES, I. R.; CAZETTA, V. Encontro para pensar gestos e restos: onde estão as imagens do improvável? In: COLÓQUIO INTERNACIONAL A EDUCAÇÃO PELAS IMAGENS E SUAS GEOGRAFIAS, 5., 2017, Florianópolis. Anais eletrônicos [...]. Florianópolis: Udesc, 2017. Disponível em: https://drive.google.com/file/d/0BwAJZeFp_ f3mUlFXNlhRQ09pR3M/view. Acesso em: 13 jul. 2020.

$\mathrm{H}_{2} \mathrm{O}$. Direção: Guy Lebrun. Produção: INCE. Rio de Janeiro, 1962.1 vídeo (5 min 33 s), son., color. Disponível em: http://www.bcc.org.br/filmes/443429. Acesso em: 5 jun. 2019.

KERR JÚNIOR,D.H.B. A produção de uma educação contemporânea: experiência com o cinema e o esquecimento. Educación Física y Deporte, v. 33, n. 1, p. 93-105, jan./jul. 2014. Disponível em: https://revistas.udea.edu.co/index.php/educacionfisicaydeporte/article/ view/20411/17242. Acesso em: 20 jun. 2021.

LEITE, C. D. P. Cinema, educação e infância: fronteiras entre educação e emancipação. Fermentário,v. 2, n. 7, p. 1-14, 2013.

LEITE, C. D. P.; CHRISTOFOLETTI, R. Pra quê cinema? O que pode o cinema na educação e a educação no cinema? Fronteiras de encontros. In: FRESQUET, A. (Org.). Cinema e Educação: A Lei 13.006 - Reflexões, perspectivas e propostas. Belo Horizonte: Universo Produção, 2015.v. 1.p. 40-50.

NOGUERA-RAMÍREZ, C. E. Pedagogia e governamentalidade ou da modernidade como uma sociedade educativa. Belo Horizonte: Autêntica, 2011.

OLIVEIRA JÚNIOR,W.M.; MARTINS,M. do C. (org.).Educação e Cultura: formação de professores e práticas educacionais. Campinas: Átomo e Alínea, 2011.v. 1.

ORGANIZAÇÃO DAS NAÇÕES UNIDAS PARA A EDUCAÇÃO,A CIÊNCIA E A CULTURA (UNESCO). Declaração mundial sobre educação para todos: satisfação das necessidades básicas de aprendizagem. Jomtien: UNESCO, 1990. Disponível em: https:// unesdoc.unesco.org/ark:/48223/pf0000086291_por. Acesso em: 5 jun. 2019.

PINHEIRO, F. L. F. Considerações iniciais sobre a análise de filmes e seu potencial para a atividade docente. In: SIRINO, S.P.M.; PINHEIRO, F.L.F. Cinema brasileiro na escola: pra começo de conversa. Curitiba: Unespar, 2014. p. 14-23.

ROSA, R. M. Produção da verdade na mídia educativa brasileira para a produção do governo de si, dos outros e de estado. 149f. Dissertação (Mestrado em Educação) Universidade Federal de Ouro Preto, Ouro Preto, 2015.

ROSE, N.Governando a alma: a formação do eu privado.In:SILVA,T.T.(Org.).Liberdades reguladas: a pedagogia construtivista e outras formas de governo do eu. 2. ed. Petrópolis: Vozes, 1988. p. 30-45. 
SCHVARZMAN, S. Humberto Mauro eas imagens do Brasil. 2000.481f.Tese (Doutorado em História) - Universidade Estadual de Campinas, Campinas, 2000.

SOUZA, J. I. M. Trabalhando com cinejornais: relatos de uma experiência. História: Questões \& Debates, Curitiba, v. 38, n. 1, p. 63-76, 2003. http://dx.doi.org/10.5380/his. v38i0.2714

TAKAHASHI, T. (Org.). Sociedade da informação no Brasil: livro verde. Brasília: Ministério da Ciência e Tecnologia, 2000.

TV ESCOLA. Portal. TV Escola. Disponível em: https://tvescola.org.br/. Acesso em: 31 maio 2019.

XAVIER, I. Um Cinema que "Educa" é um Cinema que (nos) Faz Pensar. Entrevista. Educação \& Realidade, Porto Alegre, v. 33, n. 1, p. 13-20, jan./jun. 2008. Disponível em: https://seer.ufrgs.br/educacaoerealidade/article/view/6683. Acesso em: 6 jun. 2019.

WIKIPÉDIA. A Voz do Brasil. Flórida: Wikimedia Foundation, 2019. Disponível em: https://pt.wikipedia.org/w/index.php?title=A_Voz_do_Brasil\&oldid=54973389. Acesso em: $1^{\circ}$ jun. 2019.

\section{SOBRE OS AUTORES}

Bruno da Mata Farias é mestre em estudos culturais pela Universidade de São Paulo (USP).

E-mail: brunodamata@usp.br

Valéria Cazetta é doutora em geografia pela Universidade Estadual Paulista "Júlio de Mesquita Filho"(UNESP). Professora da Universidade de São Paulo (USP).

E-mail:vcazetta@usp.br

Conflitos de interesse: Os autores declaram que não possuem nenhum interesse comercial ou associativo que represente conflito de interesses em relação ao manuscrito.

Financiamento: Parte do presente trabalho foi realizado com apoio da Coordenação de Aperfeiçoamento de Pessoal de Nível Superior - Brasil (CAPES) - Código de Financiamento 001, no período de março a dezembro de 2019.

Contribuições dos autores: Escrita — Primeira Redação: Mata, B. F. da; Escrita — Revisão e Edição: Cazetta, V. 


\section{ERRATA}

No artigo "Sociedade da aprendizagem, Instituto Nacional de Cinema Educativo (INCE) e TV Escola: governamento dos sujeitos via curtas-metragens de animação", DOI: 10.1590/S1413-24782021260044, publicado no periódico Rev Bras Educ. 2021, vol. 26, e260044:

\section{Página $19,4^{\circ}$ parágrafo}

\section{Onde se lia:}

Ao perceber a frustração da garota com a resposta do pai, o palito de fósforo (Figuras 3F e 3G) salta da caixa e responde: "Eu entendo, Kikinha. Vou te contar a minha história...”. Desse momento em diante, o palito enunciador narra desde sua própria invenção até a origem do fogo, com cortes e detalhes sobre essa cronologia.

\section{Leia-se:}

Ao perceber a frustração da garota com a resposta do pai, o palito de fósforo (Figuras 3B e 3F) salta da caixa e responde: "Eu entendo, Kikinha. Vou te contar a minha história...”. Desse momento em diante, o palito enunciador narra desde sua própria invenção até a origem do fogo, com cortes e detalhes sobre essa cronologia. 